Acta vet. scand. $1986,27,461-478$.

From the Department of Clinical Nutrition, College of Veterinary Medicine, Swedish University of Agricultural Sciences, Uppsala, Sweden, and the Department of Biochemistry, College of Veterinary Medicine, Helsinki, Finland.

\title{
COMPARATIVE EFFECT OF SELENIUM IN WHEAT, BARLEY, FISH MEAL AND SODIUM SELENITE FOR PREVENTION OF EXUDATIVE DIATHESIS IN CHICKS
}

\author{
By \\ Saifeldin Hassan
}

\begin{abstract}
HASSAN, SAIFELDIN: Comparative effect of selenium in wheat, barley, fish meal and sodium selenite for prevention of exudative diathesis in chicks. Acta vet. scand. 1986, 27, 461-478. - Groups af White Leghorn chicks obtained from dams deprived on selenium (Se), were fed from hatching a low-Se-vitamin $\mathrm{E}$ basal diet alone, or supplemented with $0.02,0.04,0.06$ or $0.08 \mathrm{mg} \mathrm{Se} / \mathrm{kg}$ diet, as sodium selenite $\left(\mathrm{Na}_{2} \mathrm{SeO}_{3} \cdot 5 \mathrm{H}_{2} \mathrm{O}\right)$, wheat, barley or fish meal. Prevention of the Sevitamin $\mathrm{E}$ deficiency responsive disease exudative diathesis (ED) as it was clinical observed, induction of the plasma Se dependent enzyme glutathione peroxidase (GSH-Px) activity, and Se concentration in the cardiac muscle were observed to be dietary Se level and source dependent. Slope ratio assay was applied to estimate the biological availability of $\mathrm{Se}$ in the natural sources relative to $\mathrm{Se}$ in sodium selenite. For the prevention of ED, the bioavailability of Se in wheat, barley and fish meal was 99,85 and $80 \%$, respectively. The increase in the plasma GSH-Px activity revealed a bioavailability for Se in wheat, barley and fish meal of 79,71 and $66 \%$, respectively. Using retention of Se in the cardiac muscle as the bioassay, a bioavailability of 108,87 and $100 \%$ was calculated for wheat, barley and fish meal Se, respectively.
\end{abstract}

selenium bioavailability; glutathione peroxidase; selenium retention; feed ingredients.

Various feedstuffs and compounds containing selenium (Se) differ widely in their ability to prevent vitamin $\mathbf{E}$ and/or Se responsive diseases and in their efficacy to restore activity of the Se dependent enzyme glutathione peroxidase (GSH-Px, glutathione-hydrogen peroxide oxido-reductase, EC 1.11.1.9) in animal 
tissues (Cantor et al. 1981). Cantor et al. (1975) using the prevention of exudative diathesis (ED) in chicks as a bioassay, determined the bioavailability of $\mathrm{Se}$ in various feedstuffs and Se compounds. These authors observed that Se from fish meals was only 15 to $25 \%$ bioavailable, while Se from plant products was 60 to $90 \%$ bioavailable, in comparison to sodium selenite. In contrast, Gabrielsen \& Opstvedt (1980) and Huque \& Jensen (1985), using the slope ratios of plasma GSH-Px activity in chicks as their indicator of bioavailability, found that the Se in fish meal had a bioavailability value 2-4 times higher than the estimate given by Cantor et al. (1975). Miller et al. (1972) reported that the amount of Se retained in chick whole body from fish meal and fish solubles was less than $50 \%$ of the amount retained from sodium selenite.

The results of Seier \& Bragg (1973) indicated that the barley and wheat Se was 52 and $70 \%$, respectively, bioavailable in preventing ED in comparison to sodium selenite. In another study, the nutritional efficacy of wheat Se in inducing erythrocyte and liver GSH-Px in rats was respectively $83 \%$ and $86 \%$ of that of sodium selenite (Douglass et al. 1981). However, rats fed wheat retained equal amounts or more Se in their tissues than rats fed sodium'selenite (Alexander et al. 1982).

Chicks deficient in Se and vitamin E, develop clinical symptoms of ED (Dam \& Glavind 1938, Scott et al. 1957) which are associated with low plasma protein content (Goldstein \& Scott 1959) and low plasma and liver GSH-Px levels (Noguchi et al. 1973, Hakkarainen et al. 1982).

Bioassays that have been used for evaluating Se bioavailability include the nutrient efficacy in preventing ED in chicks and liver necrosis in rats, increasing GSH-Px activity, and Se concentration in animal tissues (Cantor et al. 1981).

Fish meals and grains such as wheat and barley grown on areas with adequate $\mathrm{Se}$ in soil, provide a substantial portion of the dietary Se requirement for domestic animals and poultry. In view of this fact, and in view of the conflicting observations concerning Se utilization, the present study was undertaken to compare the bioavailability of Se in the above feed ingredients with that of sodium selenite using the ability of Se to prevent $\mathrm{ED}$, to elevate plasma GSH-Px activity and to increase the Se concentration in the cardiac muscle of chicks as measurements of biological availability. 


\section{MATERIAL AND METHODS}

\section{Experimental animals}

To facilitate the development of ED, chicks were obtained from hens with low Se and vitamin $\mathrm{E}$ status. One hundred and seventy five White Leghorn hens, 20 weeks of age, were housed in $43 \times 48 \times 44 \mathrm{~cm}$ wire cages, 4 hens each. The feed (Table 1) and tap water were provided ad lib. After 15 weeks on this diet, the hens were artificially inseminated with pooled semen from White Leghorn males which had been kept on a standard commercial feed sufficient in all nutrients required by the males including Se and vitamin E. Whole blood was drawn in heparinized syringes from 6 of the newly hatched, unsexed chicks through anterior cardiac puncture before they were killed. The heart was excised, and with the obtained plasma samples were subsequently stored at $-20^{\circ} \mathrm{C}$. The remaining chicks were divided randomly into 34 groups of 12 chicks each. The chicks were wing banded

T a ble 1. Composition of the basal diet fed to hens. ${ }^{12}$

\begin{tabular}{lr}
\hline & $\%$ \\
\cline { 2 - 2 } Extracted soybean meal & 23.40 \\
Barley & 24.00 \\
Wheat & 17.33 \\
Oats & 14.00 \\
Amino acid mixture & 0.60 \\
Soybean oil & 3.50 \\
Vitamin mixture & 4.04 \\
Mineral mixture & 2.61 \\
Calcium carbonate $\left(\mathrm{CaCO}_{3}\right)$ & 7.46 \\
Dicalcium phosphate $\left(\mathrm{CaHPO}_{4} \cdot 2 \mathrm{H}_{2} \mathrm{O}\right)$ & 3.06 \\
\hline
\end{tabular}

${ }^{1}$ By analysis contains $18.00 \%$ crude protein and $0.04 \mathrm{mg} \mathrm{Se} / \mathrm{kg}$.

2 Calculated content $(\%)$ : methionine + cystine 1.45 ; lysine, 1.68 .

${ }^{3}$ Supplied the following amounts $(/ \mathrm{kg}$ diet). DL-methionine, $5.00 \mathrm{~g}$; lysine, $1.00 \mathrm{~g}$.

${ }^{4}$ Supplied the following amounts(/kg diet): Vitamin A, $6500 \mathrm{IU}$; Vitamin $\mathrm{D}_{3}, 1100 \mathrm{IU}$; Vitamin $\mathrm{K}, 2.20 \mathrm{mg}$; thiamin, $2.2 \mathrm{mg}$; riboflavin, $5.50 \mathrm{mg}$; pantothenic acid, $16.50 \mathrm{mg}$; nicotinic acid, $33 \mathrm{mg}$; pyridoxin, $6.50 \mathrm{mg}$; biotin, $0.22 \mathrm{mg}$; folic acid, $0.55 \mathrm{mg}$; vitamin $\mathrm{B}_{12}$, $0.02 \mathrm{mg}$; choline chloride $50 \%, 1.30 \mathrm{~g}$; ethoxyquin, $200 \mathrm{mg}$.

${ }^{5}$ Supplied the following amounts $\left(/ \mathrm{kg}\right.$ diet): $\mathrm{KIO}_{3}, 0.83 \mathrm{mg} ; \mathrm{K}_{2} \mathrm{SO}_{4}$, $13.03 \mathrm{mg} ; \mathrm{NaCl}, 3.70 \mathrm{~g}$; $\mathrm{CuSO}_{4} .7 \mathrm{H}_{2} \mathrm{O}, 64.83 \mathrm{mg} ; \mathrm{FeSO}_{4} .7 \mathrm{H}_{2} \mathrm{O}, 0.39 \mathrm{~g}$; $\mathrm{MgSO}_{4} .7 \mathrm{H}_{2} \mathrm{O}, 8.36 \mathrm{~g} ; \mathrm{MnSO}_{4} \cdot \mathrm{H}_{2} \mathrm{O}, 0.15 \mathrm{~g} ; \mathrm{ZnSO}_{4} .7 \mathrm{H}_{2} \mathrm{O}, 0.43 \mathrm{~g}$. 
and reared in electrically-heated batteries. Room temperature was controlled. An initial room temperature of $35^{\circ} \mathrm{C}$ during the first day of hatching, was gradually reduced by $3.5^{\circ} \mathrm{C}$ a week. The relative humidity of the air was a constant $65 \%$ and artificial light was provided continuously throughout the experimental period. Feed and redistilled water were available ad lib.

\section{Experimental diets}

Spring wheat and barley enriched in Se were grown in an area deficient in Se. The fields wheat and barley were just beginning to sprout when they were sprayed with sodium selenite in a water solution (Korkman 1980). Ordinary herring fish meal produced at a commercial factory was delivered immediately

T a b l e 2. Composition of the basal diet fed to chicks. ${ }^{1}$

\begin{tabular}{|c|c|}
\hline & $\%$ \\
\hline Low-Se casein ${ }^{2}$ & 16.50 \\
\hline Extracted soybean meal ${ }^{3}$ & 7.50 \\
\hline Torula yeast & 14.70 \\
\hline Amino acid mixture ${ }^{4}$ & 0.96 \\
\hline Vitamin mixture ${ }^{5}$ & 5.00 \\
\hline Mineral mixture ${ }^{6}$ & 5.60 \\
\hline Distilled fatty acids ${ }^{7}$ & 3.00 \\
\hline Cellulose & 3.00 \\
\hline \multirow[t]{2}{*}{ Glucose } & 43.74 \\
\hline & 100.00 \\
\hline
\end{tabular}

${ }^{1}$ Calculated content $(\%)$ : methionine, 0.87 ; methionine + cystine, 1.25; lysine, 1.90 .

2 Produced as described by Bengtsson et al. (1974).

${ }^{3}$ Extracted $24 \mathrm{~h}$ with ethanol.

${ }^{4}$ Supplied the following amounts (/kg diet): DL-methionine, $2.40 \mathrm{~g}$; lysine, $1.50 \mathrm{~g}$; glycine, $2.00 \mathrm{~g}$; arginine, $2.70 \mathrm{~g}$.

5 Supplied the following amounts (/kg diet): Vitamin A, $5500 \mathrm{IU}$; Vitamin $\mathrm{D}_{3}, 1100 \mathrm{IU}$; Vitamin $\mathrm{K}, 1.40 \mathrm{mg}$; thiamin, $10.00 \mathrm{mg}$; riboflavin, $12.00 \mathrm{mg}$; pantothenic acid, $25.00 \mathrm{mg}$; nicotinic acid, 55.00 $\mathrm{mg}$; pyridoxine, $8.00 \mathrm{mg}$; biotine, $0.30 \mathrm{mg}$; folic acid, $4.00 \mathrm{mg}$; Vitamin $\mathrm{B}_{12}, 0.20 \mathrm{mg}$; choline chloride $50 \%, 4.00 \mathrm{~g}$; 1,2-dihydro-6ethoxy-2,2,4 trimethylquinoline (Ethoxyquin), $80.00 \mathrm{mg}$.

${ }^{6}$ Supplied the following amounts (/kg diet): $\mathrm{CaHPO}_{4} .2 \mathrm{H}_{2} \mathrm{O}, 37.23 \mathrm{~g}$; $\mathrm{MgSO}_{4} .7 \mathrm{H}_{2} \mathrm{O}, 7.60 \mathrm{~g} ; \mathrm{CaCO}_{3}, 5.07 \mathrm{~g} ; \mathrm{NaCl}, 5.00 \mathrm{~g} ; \mathrm{FeSO}_{4} .7 \mathrm{H}_{2} \mathrm{O}, 0.50 \mathrm{~g}$; $\mathrm{ZnSO}_{4} \cdot 7 \mathrm{H}_{2} \mathrm{O}, 0.33 \mathrm{~g} ; \mathrm{MnSO}_{4} \cdot \mathrm{H}_{2} \mathrm{O}, 0.26 \mathrm{~g} ; \mathrm{CuSO}_{4} .5 \mathrm{H}_{2} \mathrm{O}, 39.30 \mathrm{mg} ; \mathrm{K}_{2}$ $\mathrm{SO}_{4}, 6.40 \mathrm{mg} ; \mathrm{KIO}_{3}, 5.10 \mathrm{mg}$.

${ }^{7}$ Obtained from soybean oil (Hakkarainen et al. 1983). 
after processing and stored at $-20^{\circ} \mathrm{C}$. Both the wheat and the barley were milled in a Retch Laboratory mill. Each of these meals and the fish meal were then extracted separately with absolute ethanol for $24 \mathrm{~h}$ to eliminate vitamin $\mathrm{E}$, and thereafter left to dry at room temperature.

The composition of the basal diet fed to the chicks is shown in Table 2. The content of protein and Se in basal diet, low-Se casein and test ingredients fed to the chicks are shown in Table 3 . The concentrations of calcium, phosphorus and mercury in

T a ble 3. Protein and Se content of the basal diet, of the low-Se casein and of the test ingredients fed to the chicks.

\begin{tabular}{lcc}
\hline Source & $\begin{array}{c}\text { Protein } \\
\%\end{array}$ & $\begin{array}{c}\text { Se } \\
\mathrm{mg} / \mathrm{kg}\end{array}$ \\
\hline Basal diet & 23.50 & 0.03 \\
Low-Se casein & 74.20 & 0.03 \\
Barley & 11.40 & 1.50 \\
Wheat & 15.70 & 3.46 \\
Fish meal & 74.20 & 2.12 \\
\hline
\end{tabular}

the fish meal after extraction were $3.30 \%, 2.42 \%$ and $0.10 \mathrm{mg} /$ $\mathrm{kg}$, respectively. Varying amounts of either sodium selenite $\left(\mathrm{Na}_{2} \mathrm{SeO}_{3} \cdot 5 \mathrm{H}_{2} \mathrm{O}\right)$, wheat, barley or fish meal were added to the basal diet to provide Se levels of $0.02,0.04,0.06$ or $0.08 \mathrm{mg} / \mathrm{kg}$ for each respective Se source. All of the dietary treatments were formulated to contain $23.5 \%$ protein by adjusting the amount of the Se source and the low-Se casein. In the diets containing fish meal as the source of Se, the calcium carbonate and calcium phosphate content in the mineral mixture were reduced in order to keep the dietary levels of calcium and phosphorus equal in all of the treatments. The percentages of the Se source (wheat, barley or fish meal), low-Se casein and glucose in the experimental diets are presented in Table 4.

Adequate amounts of methionine and ethoxyquin were included in basal diet to protect the chicks against muscular dystrophy and nutritional encephalomalacia. By chemical analysis, the basal diet contained $0.2 \mathrm{mg}$ vitamin $\mathrm{E} / \mathrm{kg}$, while no vitamin $\mathrm{E}$ was detected in any of the extracted Se sources. This made the biologically available Se which was provided either by sodium selenite or by one of the test ingredients, the sole limiting factor 
Table 4. The content of the test ingredients, low-Se casein and glucose in the experimental diets containing natural ingredients as Se source. ${ }^{12}$

\begin{tabular}{|c|c|c|c|c|c|}
\hline \multirow[b]{2}{*}{ No. } & \multicolumn{2}{|c|}{ Diet } & \multicolumn{3}{|c|}{ Amount (\%) } \\
\hline & Se source & $\begin{array}{c}\text { Se added } \\
\mathrm{mg} / \mathrm{kg}\end{array}$ & Se source & $\begin{array}{l}\text { Low-Se } \\
\text { casein }\end{array}$ & Glucose \\
\hline 6 & Barley & 0.02 & 1.33 & 16.30 & 42.61 \\
\hline 7 & & 0.04 & 2.66 & 16.09 & 41.49 \\
\hline 8 & & 0.06 & 3.99 & 15.89 & 40.36 \\
\hline 9 & & 0.08 & 5.32 & 15.68 & 39.24 \\
\hline 10 & Wheat & 0.02 & 0.58 & 16.38 & 43.28 \\
\hline 11 & & 0.04 & 1.16 & 16.25 & 42.83 \\
\hline 12 & & 0.06 & 1.74 & 16.13 & 42.37 \\
\hline 13 & & 0.08 & 2.32 & 16.01 & 41.91 \\
\hline 14 & Fish meal & 0.02 & 0.94 & 15.56 & 43.74 \\
\hline 15 & & 0.04 & 1.88 & 14.62 & 43.74 \\
\hline 16 & & 0.06 & 2.82 & 13.68 & 43.74 \\
\hline 17 & & 0.08 & 3.76 & 12.74 & 43.74 \\
\hline
\end{tabular}

1 Diet 1 was a control, with no Se supplementation.

${ }^{2}$ Diets 2, 3, 4 and 5 were supplemented with $0.02,0.04,0.06$ or 0.08 $\mathrm{mg} \mathrm{Se} / \mathrm{kg}$, respectively, as sodium selenite $\left(\mathrm{Na}_{2} \mathrm{SeO}_{3} \cdot 5 \mathrm{H}_{2} \mathrm{O}\right)$.

for growth, the prevention of ED, the induction of plasma GSH$P x$ activity and the increase in Se concentration in the chick tissues.

\section{Experimental procedure}

Duplicate groups of chicks were fed from 1-day of age the basal diet with no added Se, (to serve as a control treatment) the basal diet supplemented with $\mathrm{Se}$ as sodium selenite, (to provide a standard response curve) or the basal diet supplemented with Se by the test feed ingredients.

The chicks were inspected daily for control of the clinical signs of ED. The observations of subcutaneous blue-green exudate on the crop, breast, abdomen, wings and legs were sufficient evidence for the diagnose of ED. When an incident was observed, blood was drawn by anterior cardiac puncture using a heparinized syringe. The heparinized blood was centrifuged at $2500 \times \mathrm{g}$ for $10 \mathrm{~min}$ to obtain plasma, which was then collected and stored at $-20^{\circ} \mathrm{C}$ until GSH-Px activity and total protein analyses. After the whole blood was drawn, the same chicks were killed, the heart was quickly excised, stored at 
$-20^{\circ} \mathrm{C}$ and then lyophilized for Se analysis. Body weight was monitored at 17 days of age. The experiment was terminated at 24 days of age when every chick on the control diet had developed ED. A plasma sample and the heart were obtained from each surviving healthy chick and were then stored at $-20^{\circ} \mathrm{C}$. A necropsy was conducted on every experimental chick in order to observe presence of visual pathological lesions of ED.

\section{Analytical methods}

Plasma protein content was determined according to the method of Weichselbaum (1948). Glutathione peroxidase activity was determined in the plasma by the method of Günzler et al. (1974) as modified by Sankari (1985). The fluorometric method (Lindberg 1968) was used to determine Se concentration. Vitamin $\mathrm{E}$ content was analysed as described by Hakkarainen et al. (1984). Protein content in both the feed ingredients and in the various diets were analysed according to A.O.A.C. (1970).

\section{Statistical analyses}

The data were subjected to analysis of variance according to Dunn \& Clark (1974). The analyses were carried out using the GLM proecdure, and pairwise comparisons were carried out using the least square means according to the Statistical Analysis System $(S A S)$. The respective efficacies of wheat, barley and fish meal Se in comparison to that of sodium selenite in preventing ED, in inducing plasma GSH-Px activity and in increasing Se concentration in the heart muscle were measured by a slope ratio assay as described by Finney (1978) utilizing the formula:

$$
\gamma=\frac{\mathrm{b}_{\text {test }}}{\mathrm{b}_{\text {standard }}} \times 100
$$

where $b$ stands for the linear regression coefficient for either one of the test ingredients or sodium selenite (standard).

\section{RESULTS}

Figure 1 shows that all of the chicks on the control diet with no Se supplement developed clinical signs of ED, and that increasing the Se level in the various diets reduced the incidence of ED. Prevention of ED was dietary Se level and source dependent. Selenium provided by sodium selenite or wheat, showed 


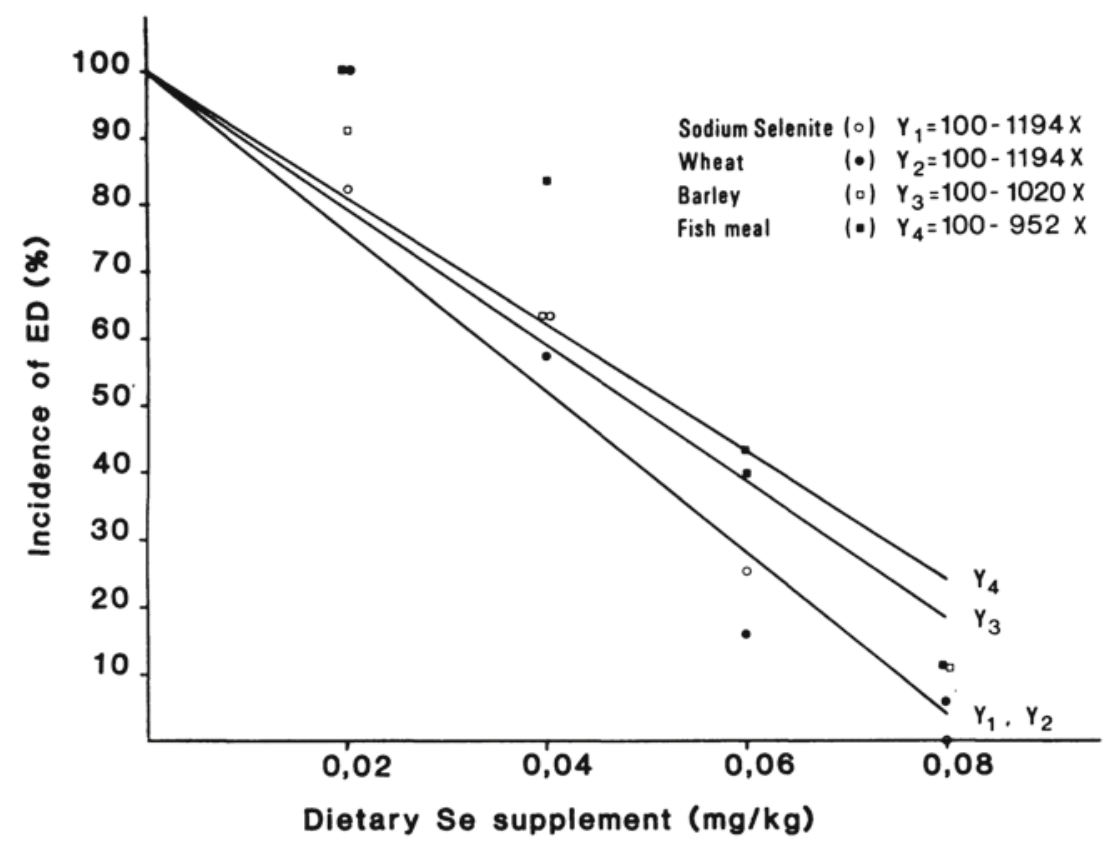

Figure 1. Relationship between the incidence of exudative diathesis $(y)$ and the dietary selenium levels supplemented by various sources $(x)$. Symbols show the percentages of chicks with clinical signs of ED in each group. $\mathrm{R}^{2}=0.88 ; \mathrm{P}<0.001$.

equal ability to prevent ED. Barley Se had an intermediate efficacy, while less preventive effect against ED was obtained by Se from fish meal. Macroscopic pathological lesions characteristic for ED were only observed during necropsy in those chicks that had developed clinical symptoms of ED. Massive subcutaneous blue-greenish exudate, haemorrhages and necrosis were observed on the inner sides of the thigh, on the neck, crop, breast and abdominal regions.

The general pattern of Se effect on the plasma GSH-Px activity and its effect on Se concentration in the cardiac muscle was similar (Table 5). Chicks with clinical signs of ED on the control diet and those receiving $0.02 \mathrm{mg} \mathrm{Se} / \mathrm{kg}$ diet showed significantly less $(P<0.05)$ plasma GSH-Px activity and Se concentration in the cardiac muscle than healthy chicks receiving $0.04 \mathrm{mg}$ Se or more $/ \mathrm{kg}$ diet. Exudative diathesis was clinically observed in chicks with $<0.3 \mathrm{U}$ GSH-Px activity/ml plasma and $<0.37 \mu \mathrm{g} \mathrm{Se} / \mathrm{g}$ cardiac muscle (dry matter). Both plasma GSH- 
Table 5. Effect of dietary Se source on plasma GSH-Px activity and cardiac muscle Se concentration.

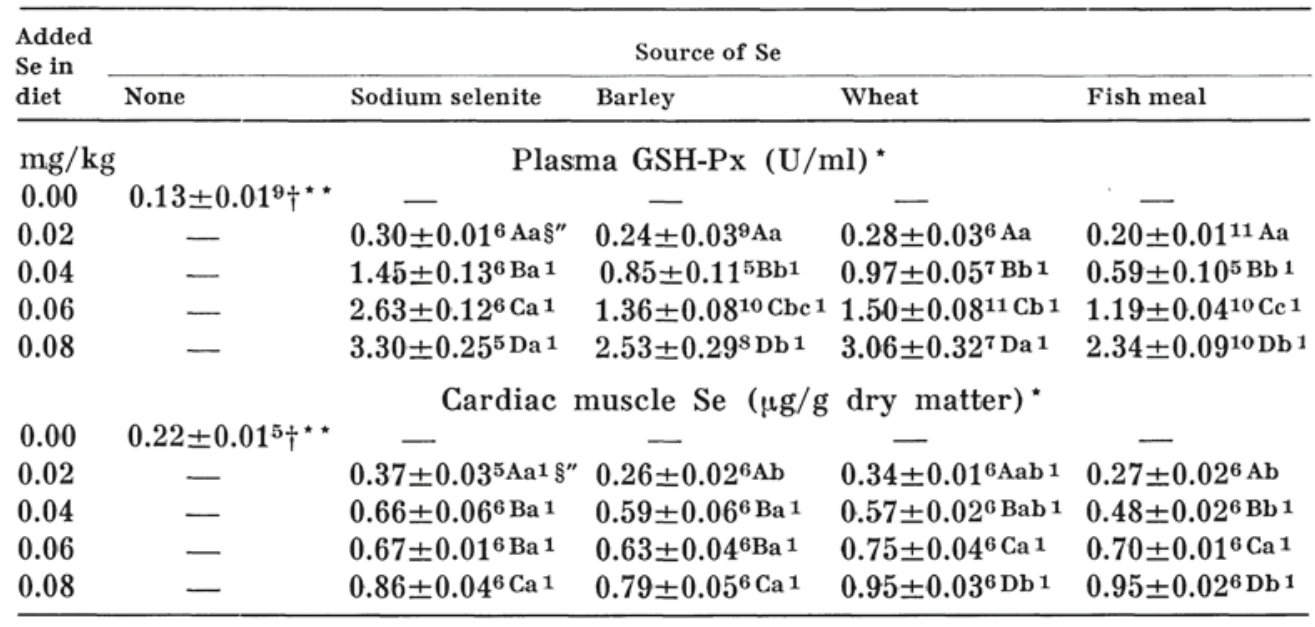

* Observations on the control diet and on the $0.02 \mathrm{mg} \mathrm{Se} / \mathrm{kg}$ diet level, are of chicks with clinical signs of ED.

$\dagger$ Plasma GSH-Px activity at hatching was $0.46 \pm 0.04 \mathrm{U} / \mathrm{ml}$. Selenium concentration in cardiac muscle at hatching was $0.50 \pm 0.05 \mu \mathrm{g} / \mathrm{g}$ dry matter.

* * Mean \pm SEM.

4-11 Number of observations per mean.

$\S$ Means within a column with no common uppercase superscript are significantly different (with at least $\mathrm{P}<0.05$ ).

"Means within a row with no common lowercase superscript are significantly different (with at least $\mathrm{P}<0.05$ ).

1 Means significantly different from the control group (with at least $\mathrm{P}<0.05)$.

Px activity and Se concentration in cardiac muscle increased with each increase in the dietary Se level from each of the various Se sources. Apart from the chicks fed the lowest level of dietary Se supplement, the plasma GSH-Px activity was significantly affected $(\mathrm{P}<0.05)$ by the Se source. When Se was provided as $0.04 \mathrm{mg}$ or more $/ \mathrm{kg}$ diet, the plasma GSH-Px activity of the chicks fed sodium selenite was significantly higher $(\mathrm{P}<0.05)$ than that in the chicks fed the other Se sources. The chicks fed barley or fish meals Se, had a comparable plasma GSH-Px activity $(\mathrm{P}>0.05)$. However, the chicks supplemented with $\mathrm{Se}$ via wheat had higher, or significantly higher $(\mathrm{P}<0.05)$ plasma GSH-Px activity in comparison to that of chicks fed barley or fish meal 
T a ble 6. Effect of dietary Se source on plasma protein content and on chick body weight.

\begin{tabular}{|c|c|c|c|c|c|}
\hline \multirow{2}{*}{$\begin{array}{l}\text { Added } \\
\text { Se in } \\
\text { diet }\end{array}$} & \multicolumn{5}{|c|}{ Source of Se } \\
\hline & None & Sodium selenite & Barley & Wheat & Fish meal \\
\hline \multicolumn{3}{|l|}{$\mathrm{mg} / \mathrm{kg}$} & \multicolumn{2}{|c|}{ Plasma protein $(\mathrm{g} / \mathrm{l})^{*}$} & \\
\hline 0.00 & $20.97 \pm 0.59^{6} \dagger^{* *}$ & - & - & - & - \\
\hline 0.02 & - & $28.24 \pm 1.77^{8} \mathrm{Aa} \S^{\prime \prime}$ & $27.32 \pm 1.69^{6 \mathrm{Aa} 1}$ & $28.28 \pm 0.94^{5} \mathrm{Aa} 1$ & $23.02 \pm 1.63^{6 \mathrm{Ab}}$ \\
\hline 0.04 & - & $33.51 \pm 1.00^{7} \mathrm{Ba} 1$ & $34.82 \pm 1.00^{6} \mathrm{Ba} 1$ & $35.15 \pm 1.10^{6} \mathrm{Ba} 1$ & $31.55 \pm 1.14^{4} \mathrm{Ba} 1$ \\
\hline 0.06 & - & $33.08 \pm 0.37^{6} \mathrm{Ba} 1$ & $35.00 \pm 0.88^{6 \mathrm{Ba} 1}$ & $34.65 \pm 1.00^{6} \mathrm{Ba} 1$ & $33.32 \pm 0.61^{6 \mathrm{Ba} 1}$ \\
\hline \multirow[t]{2}{*}{0.08} & - & $34.64 \pm 1.45^{5 \mathrm{Ba} 1}$ & $35.90 \pm 0.75^{5} \mathrm{Ba} 1$ & $32.57 \pm 1.58^{6} \mathrm{Ba} 1$ & $33.48 \pm 1.28^{6} \mathrm{Ba} 1$ \\
\hline & & & \multicolumn{2}{|c|}{ Body weight $(\mathrm{g} / \text { chick })^{* * *}$} & \\
\hline 0.00 & $195.02 \pm 12.39^{5^{\star *}}$ & - & 一 & - & - \\
\hline 0.02 & - & $212.18 \pm 21.58^{5 \mathrm{Aa}} \S^{\prime \prime}$ & $221.03 \pm 18.21^{6 \mathrm{Aa}}$ & $213.36 \pm 17.11^{5} \mathrm{Aab}$ & $195.95 \pm 20.97^{4} \mathrm{Aa}$ \\
\hline 0.04 & - & $261.96 \pm 15.19^{\top \mathrm{Ba} 1}$ & $272.85 \pm 5.64^{6 \mathrm{Ba} 1}$ & $275.90 \pm 7.19^{6 \mathrm{Ba} 1}$ & $271.30 \pm 6.74^{8 \mathrm{Ba} 1}$ \\
\hline 0.06 & - & $276.16 \pm 3.67^{\top \mathrm{Ba} 1}$ & $277.90 \pm 7.60^{9 \mathrm{Ba} 1}$ & $272.90 \pm 8.22^{12 \mathrm{Ba}}$ & $275.61 \pm 9.14^{12 \mathrm{Ba} 1}$ \\
\hline 0.08 & - & $285.84 \pm 7.97^{8 \mathrm{Ba} 1}$ & $282.39 \pm 8.42^{12 \mathrm{Ba} 1}$ & $280.91 \pm 6.36^{14 \mathrm{Ba}^{1}}$ & $291.27 \pm 10.74^{12 \mathrm{Ba} 1}$ \\
\hline
\end{tabular}

* Observations on the control diet and on the $0.02 \mathrm{mg} \mathrm{Se} / \mathrm{kg}$ diet level, are of chicks with clinical signs of ED.

$\dagger$ Plasma protein content at hatching was $30.52 \pm 0.96 \mathrm{~g} / \mathrm{l}$.

** Mean \pm SEM.

5-14 Number of observations per mean.

$\S$ Means within a column with no common uppercase superscript are significantly different (with at least $\mathrm{P}<0.05$ ).

"Means within a row with no common lowercase superscript are significantly different (with at least $\mathrm{P}<0.05$ ).

1 Means significantly different from the control group (with at least $\mathrm{P}<0.05)$.

$\cdots$ Body weight was measured at 17 days of age.

Se. The Se concentration in the heart muscle was significantly influenced $(\mathrm{P}<0.05)$ by the Se source at each supplemental level. Chicks fed wheat had higher, or significantly higher $(\mathrm{P}<0.05)$ Se concentration in the heart muscle in comparison to that of chicks fed the other Se sources.

Table 6 presents a summary of data regarding plasma protein content and chick body weight. Chicks with clinical signs of ED which were either supplemented with none or $0.02 \mathrm{mg} \mathrm{Se} / \mathrm{kg}$ diet, had significantly less $(\mathrm{P}<0.05)$ plasma protein content and significantly less $(\mathrm{P}<0.05)$ body weight as compared to apparently healthy chicks which were fed 0.04 to $0.08 \mathrm{mg} \mathrm{Se} / \mathrm{kg}$ diet. However, no significant differences $(\mathrm{P}>0.05)$ in either plasma protein content or body weight were observed among 
Table 7. Effect of dietary Se source on the age at which clinical signs of ED appeared.

\begin{tabular}{|c|c|c|c|c|c|}
\hline \multirow{2}{*}{$\begin{array}{l}\text { Added } \\
\text { Se in } \\
\text { diet }\end{array}$} & \multicolumn{5}{|c|}{ Source of Se } \\
\hline & None & Sodium selenite & Barley & Wheat & Fish meal \\
\hline $\mathrm{mg} / \mathrm{kg}$ & & The age of the chi & cks at the clinica & appearance of $\mathrm{E}$ & D (days)* \\
\hline 0.00 & $14.09 \pm 0.49^{24^{* *}}$ & - & - & - & - \\
\hline 0.02 & - & $15.93 \pm 0.85^{14} \mathrm{Aa} \S^{\prime \prime}$ & $16.15 \pm 0.75^{20 \mathrm{Aa}}$ & $15.95 \pm 0.99^{22} \mathrm{Aa}$ & $13.70 \pm 1.11^{20 \mathrm{Aa}}$ \\
\hline 0.04 & 一 & $17.92 \pm 1.47^{12} \mathrm{Aa} 1$ & $17.42 \pm 1.02^{12} \mathrm{Aa}^{1}$ & $17.08 \pm 1.05^{12 \mathrm{Aa}^{1}}$ & $16.60 \pm 1.04^{20 \mathrm{Ba}}$ \\
\hline 0.06 & 一 & $22.40 \pm 1.69^{5} \mathrm{Ba}^{1}$ & $17.89 \pm 1.01^{9} \mathrm{Aa}^{1}$ & $20.33 \pm 3.33^{3 \mathrm{Aa} 1}$ & $21.00 \pm 1.84^{9} \mathrm{Ca}$ \\
\hline 0.08 & - & - & $16.00 \pm 5.00^{2 \mathrm{Aa}}$ & $18.00 \pm 0.00^{1 \mathrm{Aa}}$ & $19.00 \pm 5.00^{2} \mathrm{ACa}$ \\
\hline
\end{tabular}

* Chicks were on experimental diets from hatching to 24 days of age.

* Mean \pm SEM.

1-2 4 Number of observations per mean.

$\S$ Means within a column with no common uppercase superscript are significantly different (with at least $\mathrm{P}<0.05$ ).

"Means within a row with no common lowercase superscript are significantly different (with at least $\mathrm{P}<0.05$ ).

1 Means significantly different from the control group (with at least $\mathrm{P}<0.05)$.

healthy chicks fed 0.04 or more $\mathrm{mg} \mathrm{Se} / \mathrm{kg}$ diet, regardless of dietary Se level or source.

Chicks fed the basal diet with no Se supplement, developed the clinical signs of ED more rapidly or significantly so $(\mathrm{P}<0.05)$ than chicks supplemented with various levels of dietary Se (Table 7). However, the Se source had no significant effect $(\mathrm{P}>0.05)$ on the age of the chicks at which ED was clinically observed. Increasing dietary Se level led to a significant delay $(\mathrm{P}<0.05)$ in the appearance of the clinical manifestations of

T a b l e 8. Biological availability of Se in the test ingredients relative to sodium selenite as measured by prevention of $\mathrm{ED}$, induction of plasma GSH-Px activity, and Se concentration in cardiac muscle.

\begin{tabular}{lccc}
\hline Bioassay used & \multicolumn{3}{c}{ Source of Se } \\
\cline { 2 - 4 } & Barley & Wheat & Fish meal \\
\hline & \multicolumn{3}{c}{ Se biological availability (\%)* } \\
Prevention of ED & 85.45 & 99.97 & 79.78 \\
Plasma GSH-Px activity & 70.72 & 79.01 & 65.63 \\
Cardiac muscle Se concentration & 86.60 & 108.26 & 99.71 \\
\hline
\end{tabular}

* Compared to sodium selenite as $100 \%$. 
ED in the chicks fed diets supplemented with Se either as sodium selenite or fish meal.

Table 8 shows the biological value of the Se in wheat, barley and fish meal for preventing ED, for elevating plasma GSH-Px activity, and for increasing the concentration of Se in the cardiac muscle, calculated by the slope ratio technique in relation to the effect of sodium selenite which was assigned a bioavailability of $100 \%$.

\section{DISCUSSION}

Exudative diathesis, a well known Se-vitamin E deficiency responsive disease in chicks, was induced in the present study by feeding newly hatched chicks a semipurified diet low in both Se and vitamin E. The low plasma protein content observed in chicks with ED, confirms the early finding by Goldstein \& Scott (1958). Likewise, the low plasma GSH-Px activity found in chicks with ED, is in accordance with Noguchi et al. (1973), Cantor et al. (1975), and Hassan (1986). On the other hand Combs et al. (1981) reported that chicks with ED had high levels of plasma GSH-Px, and they suggested that the manifestation of ED may not be directly related to plasma GSH-Px activity.

The results of the present experiment demonstrated the superior efficacy of sodium selenite in preventing ED and in increasing plasma GSH-Px activity when compared to wheat, barley and fish meal Se, and thus support the results of Cantor et al. (1975) and Douglass et al. (1981). Relatively good agreement for the various Se sources was observed between the Se bioavailability values as measured by the three responsive parameters assessed in the present study. However, when the retention of Se in the heart muscle was the criterion used, higher bioavailability estimations were observed for the Se in the tested feed ingredients. This suggested that proportionally less of the Se retained in the tissues of chicks fed wheat, barley or fish meal was utilized for the GSH-Px synthesis, and subsequently for the prevention of the disease, than from Se retained in chicks fed sodium selenite.

The present high bioavailability of wheat and barley Se agrees well with the results reported by Seier \& Bragg (1973) and Cantor et al. (1975) both of which measured the Se ability to prevent ED. However, Alexander et al. (1980) reported that rats fed low-Se basal diet supplemented with wheat had higher 
levels of blood GSH-Px than rats fed the same basal diet supplemented with sodium selenite.

The present estimation of fish meal Se bioavailability, directly supports the observations reported by Ikumo \& Yoshida (1981) and the recent study by Huque \& Jensen (1985). However, the present results agree with neither Cantor et al. (1975) who reported that Se in fish meals has only 8.5 to $25 \%$ of sodium selenite bioavailability in preventing ED, nor with Gabrielsen \& Opstvedt (1980) in their observation that Se in fish meals is 23 times more bioavailable than Se in plant products for the induction of plasma GSH-Px activity in chicks.

The high retention of fish meal Se in the chick heart muscle, is in accordance with the findings of Alexander et al. (1982), but in conflict with Miller et al. (1972) who reported lower Se concentration in the tissues of chicks fed fish meals than in chicks fed sodium selenite. Cantor et al. (1975) found that whole blood Se concenration was twice as high in chicks fed tuna meal as in chicks fed sodium selenite, even though Se from the tuna meal was only $22 \%$ as effective as sodium selenite in preventing ED.

The bioavailability for the chick of Se in feedstuffs and in Se compounds is a function of the level of Se intake, the chemical form in which Se is consumed and the presence or absence of other dietary factors which may promote or depress the biological utilization of ingested Se (Combs \& Zhou 1982). Studies with chicks have shown that Se is better utilized when provided at dietary levels below those required for optimal physiologic function (Cantor et al. 1975). Decreased GSH-Px activities have been reported in animals fed diets deficient in iron (Rodvien et al. 1974). On the other hand, the activity of this enzyme appears to be increased in response to ethoxyquin, ascorbic acid and vitamin $\mathrm{E}$ supplement in chicks receiving marginal Se levels (Combs \& Scott 1974).

The present similar bioavailability observed for wheat and barley Se may stem from the finding that most Se in wheat and probably in other grains is present as selenomethionine, (Peterson \& Butler 1962) a chemical form of Se with relatively good bioavailability for the prevention of Se responsive diseases (Schwarz \& Foltz 1958, Cantor et al. 1982).

It has been shown that the protein quality of fish meal is reduced by the presence of auto-oxidizing lipids (Tappel 1955) 
and by oxidation, which is associated with reduced Se utilization (Opstvedt 1974). Further, Huque \& Jensen (1985) found that the processing method of fish meals influenced the bioavailability of Se for chicks. The herring meal used in this study, was delivered immediately after processing and stored at $-20^{\circ} \mathrm{C}$. Thus, the storage conditions were optimal to reduce possible deterioration of the protein quality. In a recent study, Hassan et al. (1986) could not observe decrease in the utilization of Se in herring meal by the chick, as a consequence of hexane extraction. Cantor et al. (1975) did not report the storage conditions or the protein quality of the fish meals used in their study.

Interaction between mercury $(\mathrm{Hg})$ compounds and $\mathrm{Se}$ in fish meals has been suggested as a cause of reduced Se utilization (Magos \& Webb 1980). The chemical form of Se in fish meals is not yet completely determined. Lund (1973) observed that part of Se is evidently present both in lipid compounds and in the extracted fish meal. The herring meal tested in the present study contained 0.10 and $2.12 \mathrm{mg} \mathrm{Hg}$ and Se, respectively, per kg. Thus the ratio of $\mathrm{Hg}$ : Se was 0.047 , a value within the range reported for marine and fresh water fishes (Luten et al. 1980). Apparently, in the present study, as in previous studies reported by Douglass et al. (1980) and Ikumo \& Yoshida (1981), the possible interaction between $\mathrm{Hg}$ and Se did not lead to a poor utilization of Se.

The body weight observations showed here, correlate with those found by Osman \& Latshaw (1976) who reported positive response in chick body weight due to dietary Se supplement. In the present results, no significant differences were observed in the body weight of the chicks, or the age at which the clinical signs of ED were reported due to different Se sources. Therefore the results suggested that prevention of ED, induction of plasma GSH-Px and elevation of Se concentration in cardiac muscle served as a better index of Se utilization than body weight of chicks or the age at which the clinical signs of ED were observed.

The study described above compared the biological activity of Se provided by feed ingredients with that in sodium selenite. The results indicated that in preventing $\mathrm{ED}$, Se in wheat, barley and fish meal was 100,85 and $80 \%$ bioavailable, respectively. Estimates of 79,71 and $66 \%$ bioavailability, were calculated for Se in wheat, barley and fish meal, respectively, in elevating plasma GSH-Px activity. Based on Se 
efficacy in increasing Se concentration in cardiac muscle, the nutrient in wheat, barley and fish meal was 108,87 and $100 \%$, respectively, bioavailable. Apart from the efficacy of Se in fish meal in increasing Se concentration in cardiac muscle in comparison to that in barley, Se in fish meal was less utilized by the chick than Se in wheat and barley.

\section{AGKNOWLEDGEMENTS}

The author wishes to thank professor Juhani Hakkarainen, Department of Clinical Nutrition, College of Veterinary Medicine, Uppsala, Sweden, and professor Paul Lindberg, Department of Biochemistry, College of Veterinary Medicine, Helsinki, Finland, for their help and advice while conducting this investigation. The generous supply of selenium enriched wheat and barley by Ph.D. Johan Korkman, and Kemira Oy, Helsinki, Finland, and herring fish meal by Dir. Bertil österbo, Västkustfisk $\mathrm{AB}$, Gothenburg, Sweden is gratefully acknowledged. Thanks are due to M.Sc. Birgitta Vegerfors-Persson and Ph.D. Gunnar Ekbohm, the Department of Economics and Statistics, College of Agricultural Sciences, Uppsala, Sweden, for performing the statistical analyses. This investigation was supported by grants from the Swedish Council for Forestry and Agricultural Research.

\section{REFERENCES}

Alexander, A. R., P. D. Whanger \& L. T. Miller: Bioavailability to rats of selenium in various tuna and wheat products. J. Nutr. 1983, 113, 196-204.

A.O.A.C.: In: Official Methods of Analysis of the Association of Official Analytical Chemists, 11th ed. Ed.: Horwitz, W. Published by: Association of Official Analytical Chemists, Washington DC 1970, pp. 16-17.

Bengtsson, G., J. Hakkarainen, L. Jönsson, N. Lannek \& P. Lindberg: A low-selenium pig diet based on casein from selenium-deficient cows. Acta vet. scand. 1974, 15, 135-137.

Cantor, A. H., P. D. Moorhead \& M. A. Musser: Biological availability of selenium in selenium compounds and feed ingredients. In: Selenium in Biology and Medicine. Ed.: Spallholz, J. E., J. L. Martin and H. E. Ganther. OVI Publishing Company, Inc. Westport, Connecticut 1981, pp. 192-202.

Cantor, A. H., P. D. Moorhead \& M. A. Musser: Comparative effects of sodium selenite and selenomethionine upon nutritional muscular dystrophy, selenium-dependent glutathione peroxidase, and tissue selenium concentrations of turkey poults. Poult. Sci. 1982, $61,478-484$.

Cantor, A. H., M. L. Scott \& T. Noguchi: Biological availability of selenium in feedstuffs and selenium compounds for prevention of exudative diathesis in chicks. J. Nutr. 1975, 105, 96-105. 
Combs, G. F. Jr., K. T. Mandisodza, W. H. Gutenmann \& D. J. Lisk: Utilization of selenium in fly ash and in white sweet clover grown on fly ash by the chick. J. Agric. Food Chem. 1981, 29, $149-152$.

Combs, G. F. Jr. \& M. L. Scott: Antioxidant effects on selenium and vitamin E function in the chick. J. Nutr. 1974, 104, 1297-1303.

Combs, G. F. Jr. \& Y. P. Zhou: Factors affecting apparent bioavailability of selenium for the chick. Proc. Cornell Nutr. Conf. Feed Manufacture 1982, p. 36-45.

Dam, H. \& J. Glavind: Alimentary exudative diathesis, a consequence of E-avitaminosis. Nature 1939, 143, 810-811.

Douglass, J. S., V. C. Morris, J. H. Soares Jr. \& O. A. Levander: Nutritional availability to rats of selenium in tuna, beef kidney and wheat. J. Nutr. 1981, 111, 2180-2187.

Dunn, O. J. \& V. A. Clark: In: Applied Statistics. Analysis of variance and regression, 1st ed. John Wiley \& Sons, New York 1974, pp. $62-86$.

Finney, D. J.: Statistical Method in Biological Assay. 3rd ed. Alden Press, Oxford, London 1978, pp. 148-168.

Gabrielsen, B. O. \& J. Opstvedt: Availability of selenium in fish meal in comparison with soybean meal, corn gluten meal and selenomethionine relative to selenium in sodium selenite for restoring glutathione peroxidase activity in selenium-depleted chicks. J. Nutr. 1980, 110, 1096-1100.

Goldstein, J. \& M. L. Scott: An electrophoretic study of exudative diathesis in chicks. J. Nutr. 1956, 60, 349-359.

Günzler, W. A., H. Kremers \& L. Flohé: An improved coupled test procedure for glutathione peroxidase (EC. 1.11.1.9) in blood. Z. Klin. Chem. Klin. Biochem. 1974, 12, 444-448.

Hakkarainen, J., S. Hassan \& J. Työppönen: The effect of depletion of vitamin $\mathrm{E}$ and selenium on glutathione peroxidase and alphatocopherol in chicks. The Twelfth Linderstrøm-Lang Conference IUB Symposium No. 110. Selenium, Glutathione Peroxidase and Vitamin E 1982, p. 80.

Hakkarainen, J., S. Hassan, J. Työppönen \& P. Lindberg: Vitamin E deficient fat component for composing experimental diets. Acta vet. scand. $1983,24,129-132$.

Hakkarainen, R. V. J., J. T. Työppönen, S. Hassan, S. G. Bengtsson, S. R. L. Jönsson \& P. Lindberg: Biopotency of vitamin $\mathrm{E}$ in barley. Brit. J. Nutr. 1984, 52, 335-349.

Hassan, S.: Effect of dietary selenium on the prevention of exudative diathesis in chicks, with special reference to selenium transfer via eggs. Zbl. Vet. Med. A. 1986, in press.

Hassan, S., R. V. J. Hakkarainen \& P. O. Lindberg: Bioavailability to chicks of selenium in wheat and fish meal. Zbl. Vet. Med. A. 1986 , in press.

Huque, Q. M. E. \& J.F. Jensen: Biological availability of selenium and phosphorus in fish meal as affected by condition of fish and type of meal. Brit. Poult. Sci. 1985, 26, 289-297. 
Ikumo, H. \& M. Yoshida: Selenium content of feedstuffs and biological availability of selenium in chicks. Japan. Poultry Sci. 1981, 18, $307-311$.

Korkman, J.: The effect of selenium fertilizers on the selenium content of barley, spring wheat and potatoes. J. Sci. Agric. Soc. Finl. 1980, 52, 495-504.

Lindberg, P.: Selenium determination in plant and animal material, and in water. Acta vet. scand. 1968, Suppl. 23.

Lund, G.: The presence of lipid-soluble selenium compounds in marine oils. Biochem. Biophys. Acta 1973, 304, 76-80.

Luten, J. B., A. Ruiter, T. M. Ritskes, A. B. Rauchbaar \& G. Riekwelbooy: Mercury and selenium in marine and fresh water fish. J. Food Sci. 1980, 45, 416-419.

Magos, L. \& M. Webb: The interactions of selenium with cadmium and mercury. Critical Reviews in Toxicology 1980, 8, 1-42.

Miller, D., J. H. Soares, Jr., P. Bauersfeld, Jr. \& S. L. Cuppett: Comparative selenium retention by chicks fed sodium selenite, selenomethionine, fish meal and fish solubles. Poult. Sci. 1972, $51,1669-1673$.

Noguchi, T., A. H. Cantor \& M. L. Scott: Mode of action of selenium and vitamin $\mathrm{E}$ in prevention of exudative diathesis in chicks. J. Nutr. 1973, 103, 1502-1511.

Opstvedt, J.: Nutritional significance of residual lipids in fish meal. Feedstuffs 1974, 46, 22-31.

Osman, M. \& J. D. Latshaw: Biological potency of selenium from sodium selenite, selenomethionine and selenocystine in the chick. Poult. Sci. 1976, 55, 987-994.

Peterson, P. J.\& G. W. Butler: The uptake and assimilation of selenite by higher plants. Aust. J. biol. Sci. 1962, 15, 126-146.

Rodvien, R., G. Amanda \& L. R. Weintraub: Decreased glutathione peroxidase activity secondary to severe iron deficiency: A possible mechanism responsible for the shortened life span of the irondeficient red cell. Blood 1974, 43, 281-289.

SAS: Statistical Analysis System User's Guide. SAS Institute Inc., Cary, North Carolina 1982.

Sankari, $S$.: Plasma glutathione peroxidase and tissue selenium response to selenium supplementation in swine. Acta vet. scand. 1985, Suppl. 81, 1-127.

Schwarz, K. \& C. M. Foltz: Factor 3 activity of selenium compounds. J. Biol. Chem. 1958, 233, 245-251.

Scott, M. L., J. G. Bieri, G. M. Briggs \& K. Schwarz: Prevention of exudative diathesis by factor 3 in chicks on vitamin E-deficient torula yeast diets. Poult. Sci. 1957, 36, 1155.

Seier, L. \& D. B. Bragg: Influence of vitamin E and antioxidant on the response of dietary selenium by the chick and the biological activity of selenium in feed grain. Canad. J. Anim. Sci. 1973, $53,371-375$. 
Tappel, A. L.: Studies of the mechanism of vitamin E action. III. In vitro copolymerization of oxidized fats with protein. Arch. Bioch. Biophy. 1955, 54, 266.

Weichselbaum, T.E.: An accurate and rapid method for the determination of proteins in small amounts of blood serum and plasma. Amer. J. clin. Path. 1946, 16, 40-49.

\section{SAMMANFATTNING}

Komparativ effekt av selen $i$ vete, korn, fiskmjöl och natriumselenit vid förebyggandet av exudativ diates $i$ kycklingar.

Vita Leghornkycklingar efter höns utarmade på selen utfodrades från kläckning gruppvis enbart med en selen- och E-vitaminfattig basaldiet eller basaldieten supplementerad med 0.02, 0.04, 0.06 eller $0.08 \mathrm{mg}$ selen $/ \mathrm{kg}$ foder som natriumselenit, vete, korn eller fiskmjöl. Förebyggandet av kliniska symptom till den av selen-E-vitaminbrist beroende sjukdomen exudativ diates (ED), induceringen av aktiviteten av selenberoende enzymet glutation peroxidas i plasma och koncentrationen av selen i hjärtmuskeln konstaterades vara beroende både på mängden dietärt tillfört selen och på arten av selenkälla. Lineär regressionsanalys användes för att uppskatta selenets biologiska tillgänglighet $\mathrm{i}$ de naturliga fodermedlen jämfört med den för natriumselenit.

Vid förebyggandet av exudativ diates var den biologiska tillgängligheten av selen $99 \%$ i vete, $85 \%$ i korn och $80 \%$ i fiskmjöl. Induceringen av plasma glutation peroxidasaktiviteten avslöjade en biologisk tłllgänglighet av selen på $79 \%$ i vete, $71 \%$ i korn och $55 \%$ i fiskmjöl. Användningen av selenretention i hjärtmuskeln som biologiskt mått för selenets biologiska tillgänglighet gav som motsvarande siffror $108 \%$ för vete, $87 \%$ för korn och $100 \%$ för fiskmjöl.

(Received June 24, 1986).

Reprints may be requested from: Saifeldin Hassan, the Department of Clinical Nutrition, College of Veterinary Medicine, Swedish University of Agricultural Sciences, P. O. Box 7023, S-750 07 Uppsala, Sweden. 